\author{
Burchenko L., \\ Bilyk 0., \\ Bondarenko Yu., \\ Perederii I., \\ Kochubei-Lytvynenko 0.
}

\title{
INTESTIGATION OF THE EFFECT OF A MIXTURE OF SPROUTED GRAINS ON THE QUALITY AND NUTRITIONAL VALUE OF BAKERY PRODUCTS
}

Об'єктом дослідження у роботі є пшеничний хліб, збагачений сумішшю пророщених зерен. У пророщених зернах за рахунок технології замочування, процесу пророшування та висушування, зберігаються і примножуються природні властивості. Білок, що входить до складу пророщеного зерна пшениці, вівса, ячменю та кукурудзи містить всі незамінні амінокислоти, які в відсотковому відношенні становлять до 30 \% загального вмісту білку. В 5 ...10 разів більша кількість вітамінів групи В, Н, E, РР та ін. У пророщеному зерні розщеплюються всі високомолекулярні сполуки, що володіють високою поживністю $і$ легко засвоюються. Можливим недоліком використання пророщеного зерна у технологї хліба є висока автолітична активність та кислотність. Це необхідно враховувати під час удосконалення технологічного процесу.

Під час досліджень використовували суміш пророщених зерен украйнсвкого виробника ТОВ «Чойс» (м. Київ), яка має вигляд порошку, ледь солодкуватого на смак.

Встановлено, що використання суміші пророщених зерен в технології хліба пшеничного активізує бродильну активність мікрофлори тіста, сприяє застосуванню прискореної технологї. Внесення суміші пророщених зерен подовжує збереження ними свіжості виробів. Отримані результати пов'язані з покращанням живлення дріжджової мікрофлори тіста за рахунок вмісту цукрів, внесених з сумішшю пророщених зерен. Інтенсивніше забарвлення скоринки виробів є наслідком того, що продукти гідролізу крохмалю активніше вступають в реакцію меланоїдиноутворення. Уповільнення черствіння виробів з сумішшю пророщених зерен, очевидно, пов'язано з уповільненням в них ретроградацї крохмалю та накопичення низькомолекулярних декстринів за рахунок активної $\alpha$-амілази.

Завдяки дозуванню суміші пророщених зерен в кількості 5, 10 та 15 \% до маси борошна збільшується енергетична чінність хліба пшеничного відповідно до 252,7, 262,9 та 273,1 ккал порівняно з контролем 232,3 ккал. Впровадження у виробнищтво хліба з сумішшю пророщених зерен сприятиме розширенню асортименту хлібобулочних виробів геродієтичного призначення.

Ключові слова: хліб пшеничний, суміш пророщених зерен, активність мікрофлори тіста, свіжість хліба.

\section{Introduction}

Nutrition with an optimal ratio of full-fledged proteins, macro- and microelements, vitamins, polyunsaturated fatty acids is one of the necessary conditions for the functioning of body systems [1]. Bakery products are the most common food, especially among people of older age groups. Increasing their biological value by introducing products of unconventional raw materials rich in biologically active substances is the most effective way [2].

Gerodietary nutrition prevents the most common diseases of the elderly, such as diabetes, diseases of the musculoskeletal system (arthritis, osteoporosis), gastrointestinal tract, cardiovascular diseases, diseases of the organs of vision. As people of older age groups belong to the group of increased risk, healthy and adequate nutrition with sufficient content of macro and microelements, vitamins D, A, E, C, Group B, proteins and peptides (collagen) necessary for building bone and cartilage tissue, polyunsaturated fatty acids, probiotics and prebiotics, is a necessary condition [3, 4]. Also, the presence of biologically active substances in the daily diet of older people will reduce the speed of aging processes [5]. Therefore, the development of nutritional products with functional properties is very important in terms of the pace of modern life. At the world level, it is proved that in the case of production of gerodietary products, the most appropriate partial replacement of traditional raw materials for non-traditional, the introduction of food and dietary supplements, the use of secondary raw materials. This allows to create a balanced by all criteria products for the elderly, the production of which takes into account all the age features [6].

One of the sources of healthy nutrition is sprouted cereal grains: wheat, oats, barley, corn. Sprouted grains include the entire set of ingredients necessary for a balanced diet: proteins, easily digestible carbohydrates, fiber, fatty acids, minerals, vitamins, as well as enzymes [7]. Thanks to this composition, these components of the mixture act as synergists, supporting and enhancing the effect of each other. Due to the balanced amino acid composition of the protein, the content of dietary fiber, vitamins, etc., a mixture of sprouted grains acts as a valuable and affordable source for the enrichment of bakery products. Also in a mixture of preserving virtually all substances contained in the whole grain, and this is very important, given the loss that the chemical composition of the grain will incur during the production of flour from it. A mixture of sprouted grains is the most promising ingredient in the technology of bakery products for people of older age groups [8]. 
Therefore, it is relevant today to develop formulations of bakery products for other purposes that have a more balanced nutritional value, namely the use of a mixture of sprouted grains in their recipe.

\section{The object of research and its technological audit}

The object of research in the work is bread made from wheat flour of the highest grade, enriched with a mixture of sprouted grains of wheat, barley, oats and corn. Chemically, wheat bread is not balanced for essential nutrients, namely, proteins, dietary fiber, unsaturated fatty acids, and vitamins. To improve the balance of bakery products by chemical composition and make the products health-improving properties, it is advisable to use non-traditional raw materials containing physiologically functional ingredients.

A mixture of sprouted grains of wheat, barley, oats and corn from the company Choice LLC (Kyiv, Ukraine) was used as an unconventional raw material.

Sprouted grains are a biologically active product. Due to the special technology of soaking, the sprouting process and the final stage - drying, the grains are not only preserved, but also their natural properties are multiplied [8]. The protein contained in the sprouted grain of wheat, oats, barley and maize contains all the essential amino acids, which in percentage are up to $30 \%$ of the total protein content. 5...10 times more vitamins of group B, H, E, PP, etc. All high molecular weight compounds with high nutritional value are split into sprouted grains [9].

The chemical composition and quality indicators of a mixture of sprouted grains are given in Table 1.

Table 1

The chemical composition and quality indicators of a mixture of sprouted grains

\begin{tabular}{|l|c|}
\hline \multicolumn{1}{|c|}{ Indicator } & Content \\
\hline Moisture content, \% & 12.0 \\
\hline Mass fraction of protein, \% & 10.6 \\
\hline Mass fraction of carbohydrates, \% & 60.5 \\
\hline Mass fraction of fat, \% & 2.7 \\
\hline Mass fraction of ash, \% & 0.9 \\
\hline Acidity, hail & 9.0 \\
\hline Autolytic activity, \% DM & 55.5 \\
\hline
\end{tabular}

Note: DM - dry matter

Given the chemical composition of the mixture of sprouted grains, it can be argued that it is an effective source of soluble dietary fiber, protein, vitamins and minerals. However, perhaps the disadvantage of its use in bread technology is high autolytic activity and acidity. This must be considered when improving the process.

\section{The aim and objectives of research}

The aim of research is establishing the influence of the mixture of sprouted grains on the quality of wheat bread from high-grade flour, if introduced, to improve the nutritional value of the products.
To achieve the aim it is necessary to:

1. Establish the optimal dosage of the mixture of sprouted grains in the recipe of wheat bread.

2. Investigate the effect of a mixture of sprouted grains on the activity of the fermentation microflora.

3. Investigate the effect of a mixture of sprouted grains on the preservation of freshness products.

\section{Research of existing solutions of the problem}

Bakery products are the main food products, the average daily consumption of which is about $300 \mathrm{~g}$. However, bakery products made from wheat flour of the highest grade have a low biological value compared to products from lower grades of flour [2].

Non-traditional raw materials are used to improve the quality, nutritional value and provide bakery products of gerodietary properties. There are sprouted wheat, oats, corn, barley $[5,10]$.

Flour from sprouted wheat grain has a high content of amino acids, fatty acids, vitamins B1, B2, B3, B6, B9 and $\mathrm{E}$ and 21 times higher content of dietary fiber compared to wheat flour [9]. The authors [11] investigate the possibility of replacing the bread in the recipe of wheat flour with flour from sprouted grain in an amount of from $5 \ldots 20 \%$ by weight of the flour. It is established that such a replacement improves the nutritional value of bread, increases the amount of protein in it, along with it worsens the digestibility of starch. But this work does not indicate the effect of such a replacement on the parameters of the technological process of manufacturing products.

Studies $[12,13]$ show that using sprouted wheat grain in an amount of $1.5 \%$ by weight of flour increases the amount of emitted carbon dioxide, the volume of bread and the rheological characteristics of the crumb are improved. However, these studies did not indicate the effect of wheat sprouted grains on the stale bread and the possibility of increasing the dose.

In work [14] it is indicated that as a result of the use of oat malt flour, the dough from wheat flour acquires visco-plastic properties due to the activity of proteolytic enzymes. So, in the case of imparting $10,30,50 \%$ oat malt flour dilution dough increases 1.4 times, the maximum consistency according to the analysis of farinogram increases. It is also noted that with the introduction of this flour the content of amino acids and vitamins increases, but the effect on the fermentation activity of yeast and the degree of preservation of freshness is not indicated.

After barley sprouting, the amount of starch in it decreases and thus the content of dextrins increases accordingly [15]. It is known that by increasing the content of dextrins in bakery products, the process of staling is slowed down [16]. Therefore, the use of flour from sprouted barley grain is advisable to slow down the process of staling the bread from wheat flour.

Sprouted corn kernels are known to contain a high amount of B vitamins, tocopherol, selenium, manganese, magnesium, phosphorus, zinc, and chromium. Many studies are carried out in the case of the use of processed corn products in the technology of bakery products [17], but there are no studies on the use of sprouted grain.

Studies [18] have shown the promise of using sprouted grains as a source of vitamins, minerals, and easily digestible 
carbohydrates. It is noted that the addition of flour from sprouted grain can improve the functional properties of the product, but in the case of increasing the dosage, the organoleptic and physico-chemical indicators of the quality of bread deteriorate [19].

The authors of [20] determined the optimal dosages and proved the possibility of using flour from sprouted grains in the production of functional bakery products. Their positive effect on the activity of the fermentation microflora of the test is established [21]. However, both in this work and in previous ones it is noted that the limiting factor of using such products is their dosing due to the activity of enzymes. Therefore, the use of a mixture of sprouted grains is promising for improving the nutritional value of bakery products.

Thus, the results of the analysis of literary sources have shown that it is promising to investigate the optimal dosage of the mixture of sprouted grains on the quality of bakery products.

\section{Methods of research}

Laboratory researches were carried out to study the indicators of the technological process, biochemical, physicochemical changes in the dough and the quality indicators of bread. The dough was kneaded in an Esher kneader (Italy) for 4 minutes at the first speed and 7 minutes at the second speed. The dough was prepared in an accelerated way with a mass fraction of the dough moisture $44.0 \%$. The fermentation process was replaced with trailing, which was carried out for 20 minutes. Dough processing was carried out manually, dough was made in a cabinet in a cabinet at a temperature of $38 \pm 2{ }^{\circ} \mathrm{C}$ and relative humidity of $78 \pm 2 \%$ until ready. Products were baked in cupboard ovens at a temperature of $220 \ldots 240{ }^{\circ} \mathrm{C}$ with moistening of the baking chamber.

Gas outlet capacity of semi-finished products was determined on the device AG-1M (Russia) [22]. The gas- retaining ability of the dough was characterized by the value of the specific volume of the dough after 4 hours of its fermentation: dough samples weighing $100 \mathrm{~g}$ were placed in a cylinder of $500 \mathrm{~cm}^{3}$, compacted and fermented at $30{ }^{\circ} \mathrm{C}$.

Yeast fermentation activity was determined by the method of yeast lift [23] after punching. The punching operation was repeated twice.

The quality of bread was evaluated by physicochemical (specific volume, dimensional stability, structural and mechanical properties of the crumb) and organoleptic characteristics (appearance, surface of the crust, the structure of porosity, taste, smell). The duration of preservation of freshness products was investigated with a change in the structural and mechanical properties of the crumb. Its total deformation was determined after 48 hours of storage at AP 4/1 penetrometers (Germany) [23]. The staling degree of the products was also investigated for the crunch of the bread crumb.

The results of experimental studies were subjected to statistical processing, implemented using standard software packages Microsoft Office.

\section{Research results}

To establish the technological efficiency and determine the optimal dosage of the mixture of sprouted grains in the production of bakery products, studies were conducted to determine its effect on the technological process and the quality of the products.

When conducting research, products were baked with a mixture of sprouted grains in the amount of 5,10 and $15 \%$ by weight of flour. Products without a mixture of sprouted seeds served as a control.

Analysis of the obtained data (Table 2) shows that the introduction of a mixture of sprouted grains significantly affects the titratable acidity of the dough and finished products. The dough with a mixture of sprouted grains felt more sticky and viscous than the dough samples with a corresponding dosage of the mixture of sprouted grains.

Table 2

The effect of a mixture of sprouted seeds on the quality indicators of dough and finished products

\begin{tabular}{|c|c|c|c|c|}
\hline \multirow{2}{*}{ Indicator } & \multirow{2}{*}{ Control } & \multicolumn{3}{|c|}{ Sprouted grain mixtures \% by weight of flour are added } \\
\hline & & 5 & 10 & 15 \\
\hline \multicolumn{5}{|c|}{ Dough } \\
\hline Humidity, \% & \multicolumn{4}{|c|}{44.0} \\
\hline Relaxation duration, min & \multicolumn{4}{|c|}{20} \\
\hline $\begin{array}{l}\text { Acidity, degree: } \\
\text { - initial; } \\
\text { - final }\end{array}$ & $\begin{array}{l}1.6 \\
2.0\end{array}$ & $\begin{array}{l}1.8 \\
2.2\end{array}$ & $\begin{array}{l}2.0 \\
2.4\end{array}$ & $\begin{array}{l}2.2 \\
2.6\end{array}$ \\
\hline Dissolution of dough balls, mm & 72 & 78 & 90 & 98 \\
\hline $\begin{array}{l}\text { Gas formation in dough during relaxation } \\
\text { and proofing, } \mathrm{cm}^{3} / 100 \mathrm{~g} \text { of dough }\end{array}$ & 812 & 828 & 1020 & 992 \\
\hline \multicolumn{5}{|c|}{ Finished goods } \\
\hline Specific volume, $\mathrm{cm}^{3} / \mathrm{g}$ & 2.98 & 2.81 & 2.72 & 2.63 \\
\hline Formability, $\mathrm{H} / \mathrm{D}$ & 0.47 & 0.47 & 0.32 & 0.25 \\
\hline Porosity, \% & 78.0 & 76.0 & 75.0 & 73.0 \\
\hline Acidity, hail & 1.8 & 2.0 & 2.2 & 2.4 \\
\hline Surface condition and color & \multicolumn{2}{|c|}{$\begin{array}{l}\text { 5mooth without cracks } \\
\text { and explosions, light yellow }\end{array}$} & $\begin{array}{l}\text { Smooth, without cracks and } \\
\text { explosions, cream color }\end{array}$ & $\begin{array}{l}\text { Smooth without cracks and } \\
\text { explosions, golden brown }\end{array}$ \\
\hline Сrumb color & \multicolumn{2}{|c|}{ Light white } & Light with a gray tint & Gray \\
\hline Porosity structure & \multicolumn{3}{|c|}{ Thin-walled uniform } & Thin-walled uneven \\
\hline Taste and aroma & $\begin{array}{c}\text { Characteristic of } \\
\text { this type of product }\end{array}$ & \multicolumn{3}{|c|}{ Pleasant taste and aroma, taste of sprouted seeds } \\
\hline
\end{tabular}


It is established that when using a mixture of sprouted grains, the titratable acidity increases, this is due to the high acidity of the sprouted grains.

An increase in the spreading and a decrease in the form-stability of the finished products are also observed, this is due to the high autolytic activity of the sprouted mixture of grains.

There is also a greater release of carbon dioxide during the fermentation of dough samples with a mixture of sprouted grains compared to the control, as a result of the activation of the fermentation microflora of the dough.

To confirm this, let's determine the influence of the mixture of sprouted grains on the vital activity of the yeast microflora of the dough. The research results are summarized in Table 3 .

Table 3

Dough lifting speed with a mixture of sprouted grains, min

\begin{tabular}{|c|c|c|c|c|}
\hline \multirow{2}{*}{ Indicator } & \multirow{2}{*}{ Control } & \multicolumn{3}{|c|}{$\begin{array}{c}\text { Dosage of sprouted grain mixture, \% by } \\
\text { weight of flour }\end{array}$} \\
\cline { 3 - 5 } & & 5 & 10 & 15 \\
\hline First lifting & 91 & 86 & 80 & 78 \\
\hline Second lifting & 34 & 32 & 30 & 30 \\
\hline Third lifting & 28 & 24 & 22 & 20 \\
\hline Total & 153 & 142 & 132 & 128 \\
\hline
\end{tabular}

It is proved that the use of a mixture of sprouted grains reduces the duration of the rise of the dough compared to the control by $7 \ldots 16.0 \%$.

It is noted that the gas output capacity of the test samples increased slightly and was close to control (Fig. 1). Probably a slight increase in this indicator is associated with an increase in the amount of carbon dioxide emitted during the period of preparation and proofing of dough pieces. Along with this, the gas-holding ability of the dough is provided by the ability of the gluten carcass of the test system to retain carbon dioxide, and in a short period of caking and proofing of the test, active proteolysis of protein substances does not occur, which would worsen this property.

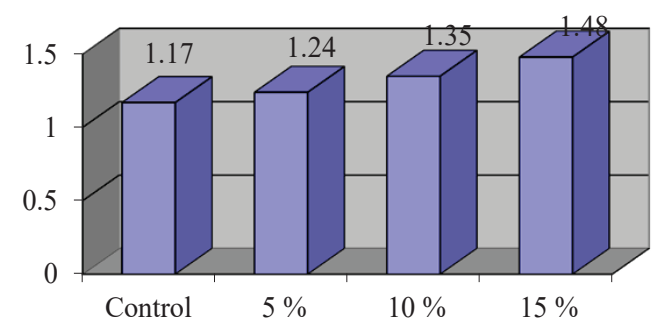

Fig. 1. Specific dough volume

The research results have established that the use of a mixture of sprouted grains makes it possible to obtain finished products of good quality, but their quality indicators are lower compared with the control. Thus, according to the organoleptic characteristics of the product, with a mixture of sprouted grains, the color of the crust was somewhat more intense. Obviously, this is due to the fact that about $15 \%$ of the split starch is added to the dough with a mixture of sprouted grains, the ingredients of which actively react to melanoid formation. It is also found that products made from a mixture of sprouted seeds have a pleasant, more pronounced compared to the control, the taste and aroma inherent in malt.

The specific volume of products from sprouted grain is less than the control sample by $5.7 \ldots 11.7 \%$. This can be explained by the fact that the introduction of a mixture of sprouted grains in the dough reduces the viscosity of the products and increases the spreading, which causes a smaller volume of finished products.

Thus, the results of the conducted research prove the possibility of using a mixture of sprouted grains for enriching bakery products with nutrients that are important for the human body.

In the bread making technology, a mixture of sprouted grains, as a raw material, not only affects the organoleptic properties of products, but also affects their freshness preservation.

A mixture of sprouted grains slows down the retrogradation of the starch of the crumb and increases its hydrophilic properties, which allows to maintain the freshness of the products within $24 \ldots 72$ hours.

The study of products was carried out after 4, 24, 48 and 72 hours after preparation.

It is established (Table 4), the total deformation of the crumb of products with a mixture of sprouted grains is higher than in the control.

Table 4

Change of structural and mechanical properties of bread crumb with a mixture of sprouted grains

\begin{tabular}{|c|c|c|c|c|}
\hline \multirow[t]{2}{*}{ Indicators } & \multirow{2}{*}{$\begin{array}{l}\text { Control } \\
\text { (without } \\
\text { additives) }\end{array}$} & \multicolumn{3}{|c|}{$\begin{array}{l}\text { Sprouted grain mixtures \% } \\
\text { by weight of flour аге added }\end{array}$} \\
\hline & & 5 & 10 & 15 \\
\hline \multicolumn{5}{|c|}{ Crumb deformation, device units after 4 hours: } \\
\hline Total & 86 & 88 & 88 & 90 \\
\hline \multicolumn{5}{|c|}{ after 24 hours: } \\
\hline Total & 58 & 64 & 66 & 68 \\
\hline $\begin{array}{l}\text { Freshness preservation } \\
\text { degree, \% }\end{array}$ & 67 & 73 & 75 & 76 \\
\hline \multicolumn{5}{|c|}{ after 48 hours: } \\
\hline Total & 35 & 42 & 47 & 51 \\
\hline $\begin{array}{l}\text { Freshness preservation } \\
\text { degree, \% }\end{array}$ & 44 & 48 & 53 & 57 \\
\hline \multicolumn{5}{|c|}{ after 72 hours: } \\
\hline Total & 22 & 26 & 28 & 35 \\
\hline $\begin{array}{l}\text { Freshness preservation } \\
\text { degree, \% }\end{array}$ & 26 & 30 & 32 & 39 \\
\hline
\end{tabular}

During storage, indicators of the structural and mechanical properties of the crumb with inulin decreased more slowly than in the control. So, after 72 hours, the freshness preservation degree of the control sample is $26 \%$, respectively, while samples with a mixture of sprouted grains are 30,32 and $39 \%$, respectively, which is $15 \ldots 50 \%$ more compared to the control.

Slowing down of staling of products with a mixture of sprouted seeds, obviously, is due to the slowing down in it of starch retrogradation to a greater extent than in the crumb of the control sample. This is due to the presence of active $\alpha$-amylase, under the action of which 
low molecular weight dextrins accumulate, which slow down the process of staling.

In the process of staling of the pore walls of the crumb, the products lose their strength, which leads to an increase in the crush of the crumb. The research results (Fig. 2) show that the crush value of the crumb is lower for bread with a mixture of sprouted grains than in the control sample. Thus, the use of a mixture of sprouted grains in the technology of bakery products contributes to the lengthening of the duration of their implementation.

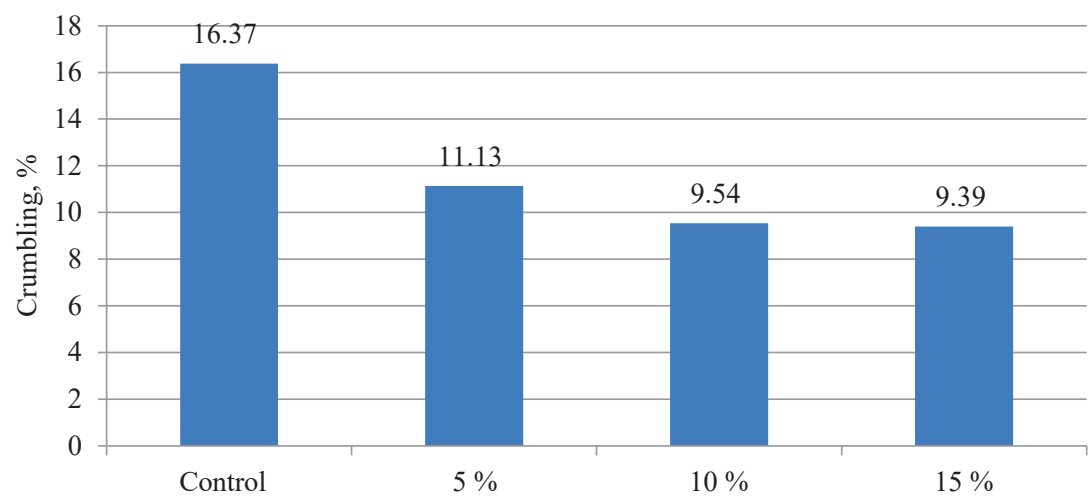

Fig. 2. Crumbling of product crumb with a mixture of sprouted grains

In the case of dosing a mixture of sprouted grains of 5,10 and $15 \%$ by weight of the flour, the energy value increases to $252.7,262.9$ and $273.1 \mathrm{kcal}$, compared with $232.3 \mathrm{kcal}$ in the control sample. That is, in the case of using a mixture of sprouted grains in the technology of wheat bread, the energy value is improved.

As a result of the conducted research, an optimal dosage of the mixture of sprouted grains is $10 \%$ by weight of the flour. This dosage to a lesser extent adversely affects the organoleptic and physico-chemical indicators of the quality of bread according to the accelerated technology.

\section{SWOT analysis of research results}

Strengths. It is established that the addition of a mixture of sprouted grains contributes to the lengthening of the freshness of products up to 72 hours of storage.

The use of a mixture of sprouted grains in the recipe of wheat bread from high-grade flour in the amount of 5, 10 and $15 \%$ by weight of flour increases their energy value.

That is, these products can increase the range of bakery products for family use due to increased nutritional value and long shelf life. This is due to the fact that nutritionists recommend older people to consume bakery products from yesterday's pastries.

Weaknesses. The use of a mixture of sprouted grains in the technology of wheat bread from flour of the highest grade will increase the cost of products.

Opportunities. Analysis of research results indicates the feasibility of using a mixture of forgive grains in the technology of wheat bread and the feasibility of further research on:

- development of new bakery products gerodietary destination and increased nutritional value;

- in-depth study of the effect of a mixture of sprouted grains on the formation of the structural and mechanical properties of semi-finished products;
- establishment of modes of the technological process and the possibility of using food additives to inactivate $\alpha$-amylase;

- mold formation during storage.

In the case of the introduction of new bread with a mixture of sprouted grains at the baking enterprises will contribute to the expansion of the range of products for gerodietary destination.

Threats. Taking into account that the Ukrainian firm «Choice» is the producer of the sprouted grains mix, the main factors affecting the stability of bakery production are price fluctuations of the sprouted grains mix, due to the increased energy costs for their production.

\section{Conclusions}

1. It is established that the optimal dosage of sprouted grains in the wheat bread recipe is $10 \%$ by weight of the flour. Such a dosage allows the use of accelerated technology, namely the dough method of synthetic preparation, in which the duration of fermentation is replaced with a technological process of trailing, which lasts 20 minutes.

2. It is noted that the introduction of a mixture of sprouted grains improves the fermentation activity of the microflora of the dough, as evidenced by $2.0 \ldots 22.0 \%$ more than the amount of carbon dioxide released and 11-15 minutes less than the lifting force of the dough.

3 . It is proved that as a result of the use of a mixture of sprouted grains, the preservation of freshness increases, as evidenced by a decrease in the crumb of the products and slowing changes in the structural and mechanical properties of the crumb during storage.

\section{References}

1. Bruce R. Hamaker Technology of Functional Cereal Products. Cambridge Woodhead Publishing Limited, 2008. 568 p. doi: http://doi.org/10.1533/9781845693886

2. Research into effectiveness of using the integrated bread baking improver «Mineral Freshness ${ }^{+} »$ to slow down the staling of bakery products / Bilyk O. et. al. // Eastern-European Journal of Enterprise Technologies. 2018. Vol. 4, Issue 11 (94). P. 69-78. doi: http://doi.org/10.15587/1729-4061.2018.140333

3. Marti A. Sprouted wheat as an alternative to conventional flour improvers in bread-making. Italy: Food quality and preference, 2015

4. Paliienko O. V. Istorychni aspekty stanovlennia ta rozvytku vitchyznianoi herontolohii: vnesok akademika V. V. Frolkisa u naukovi poshuky mekhanizmiv starinnia ta zasobiv prodovzhennia tryvalosti zhyttia // Etnichni istoriia narodiv Yevropy. 2013. Issue 40. P. 159-163.

5. Baik M.-Y., Chinachoti P. Moisture Redistribution and Phase Transitions During Bread Staling // Cereal Chemistry Journal. 2000. Vol. 77, Issue 4. P. 484-488. doi: http://doi.org/10.1094/ cchem.2000.77.4.484

6. Bronswijk J. E. M. H. V. Gerontechnology starts at birth and even earlier // Gerontechnology. 2014. Vol. 13, Issue 2. doi: http://doi.org/10.4017/gt.2014.13.02.021.00

7. Otrymannia biolohichno-aktyvnoho produktu «Proroshchen zerna»: Pat. No. 46340 UA. MPK A23L 1/172 (2009.12) Miliutin O. I., Varhanova I. V., Potapenko S. I. No. u200911217; declareted: 05.11.2009; published: 10.12.2009, Bul. No. 23.

8. Proroshcheni zerna. URL: http://company.choice.ua/uk/product 
9. Koryachkina S. Ya., Kuznetsova E. Ya., Prigarrina O. M. Sovershenstvovanie tekhnologii khleba na osnove tselogo zerna pshenitsy i rzhy // Vestnik OGU. 2006. Issue 9 (2). P. 284-288.

10. Wilmonth J. M., Kennet F. F. Gerontology: perspectives and issues. New York: Springer Publishing Company, 2013. 350 p.

11. Świeca M., Dziki D., Gawlik-Dziki U. Starch and protein analysis of wheat bread enriched with phenolics-rich sprouted wheat flour // Food Chemistry. 2017. Vol. 228. P. 643-648 doi: http://doi.org/10.1016/j.foodchem.2017.02.052

12. Kravchenko M. F., Kryvoruchko M. Yu., Pop T. M. Boroshno z proroshchenoho zerna pshenytsi yak osnova dlia boroshnianykh kulinarnykh i kondyterskykh vyrobiv // Kharchova nauka i tekhnolohiia. 2017. Issue 12. P. 6-10.

13. Marti A. et. al. Flour from sprouted wheat as a new ingredient in bread-making // LWT. 2018. Vol. 89. P. 237-243. doi: http://doi.org/10.1016/j.lwt.2017.10.052

14. Mäkinen O. E., Arendt E. K. Oat malt as a baking ingredient - A comparative study of the impact of oat, barley and wheat malts on bread and dough properties // Journal of Cereal Science. 2012. Vol. 56, Issue 3. P. 747-753. doi: http:// doi.org/10.1016/j.jcs.2012.08.009

15. Gous P. W., Fox G. P. Review: Amylopectin synthesis and hydrolysis - Understanding isoamylase and limit dextrinase and their impact on starch structure on barley (Hordeum vulgare) quality // Trends in Food Science \& Technology. 2017. Vol. 62. P. 23-32. doi: http://doi.org/10.1016/j.tifs.2016.11.013

16. Starch: chemistry and technology / ed. by BeMiller J., Whistler R. Burlington: Academic press, 2009. 879 p.

17. Gül H., Özer M. S., Dizlek H. Improvement of the wheat and corn bran bread quality by using glucose oxidase and hexose oxidase // Journal of Food Quality. 2009. Vol. 32, Issue 2. P. 209-223. doi: http://doi.org/10.1111/j.1745-4557.2009.00246.x

18. Bueno M. M., Thys R. C. S., Rodrigues R. C. Microbial Enzymes as Substitutes of Chemical Additives in Baking Wheat Flour Part II: Combined Effects of Nine Enzymes on Dough Rheology // Food and Bioprocess Technology. 2016. Vol. 9, Issue 9. P. 1598-1611. doi: http://doi.org/10.1007/s11947-016-1744-8

19. Finnie S., Brovelli V., Nelson D. Sprouted grains as a food ingredient // Sprouted Grains. 2019. P. 113-142. doi: http:// doi.org/10.1016/b978-0-12-811525-1.00006-3
20. Pshenyshniuk H. F., Makarova O. V., Ivanova H. S. Innovatsiini zakhody pidvyshchennnia yakosti zernovoho khliba // Kharchova nauka i tekhnolohiia. 2010. Issue 1 (10). P. 73-76.

21. Olaerts H., Vandekerckhove L., Courtin C. M. A closer look at the bread making process and the quality of bread as a function of the degree of preharvest sprouting of wheat (Triticum aestivum) // Journal of Cereal Science. 2018. Vol. 80. P. 188-197. doi: http://doi.org/10.1016/j.jcs.2018.03.004

22. Lebedenko T. Ie., Pshenyshniuk H. F., Sokolova N. Iu. Tekhnolohiia khlibopekarskoho vyrobnytstva. Praktykum: textbook. Odessa: Osvita Ukrainy, 2014. 392 p.

23. Tekhnokhimichnyi kontrol syrovyny ta khlibobulochnykh i makaronnykh vyrobiv: textbook. Kyiv: NUKhT, 2015. 902 p.

Burchenko Liudmyla, Assistant, Department of Bakery and Confectionary Goods Technology, National University of Food Technologies, Kyiv, Ukraine, e-mail: L27 burchenko@ukr.net, ORCID: http:// orcid.org/0000-0002-5413-961X

Bilyk Olena, PhD, Associate Professor, Department of Bakery and Confectionary Goods Technology, National University of Food Technologies, Kyiv, Ukraine, e-mail: bilyklena@gmail.com, ORCID: http://orcid.org/0000-0003-3606-1254

Bondarenko Yulia, PhD, Associate Professor, Department of Bakery and Confectionary Goods Technology, National University of Food Technologies, Kyiv, Ukraine, e-mail: bjuly@ukr.net, ORCID: http:// orcid.org/0000-0002-3781-5604

Perederii Inna, Department of Bakery and Confectionary Goods Technology, National University of Food Technologies, Kyiv, Ukraine, e-mail: innakleo12@gmail.com, ORCID: http://orcid.org/0000-00020662-5920

Kochubei-Lytoynenko Oksana, PhD, Associate Professor, Director of Institute, Educational and Scientific Institute of Food Technologies, National University of Food Technologies, Kyiv, Ukraine, e-mail: okolit@email.ua, ORCID: http://orcid.org/0000-0003-0712-448X 